\title{
PENGARUH TRANSFER PEMERINTAH PUSAT DAN FISKAL STRESS TERHADAP BELANJA DAERAH DI PROVINSI PAPUA BARAT
}

\author{
Lillyani Margaretha Orisu' \\ liornoel@yahoo.com \\ Rumas Alma Yap ${ }^{2}$ \\ rumasalmayap231984@gmail.com \\ Hesty Theresia Salle ${ }^{3}$ \\ hezty.salle@gmail.com
}

\begin{abstract}
This research aims to examine the effect of central government transfers, fiscal stress, regional taxes and gross regional domestic product on regional spendingofdistricts/cities in West Papua Province, to analyze the effect of fiscal stress from two indicators, namely the ratio of local revenue to regional spending and the difference in expenditurewith revenue. Using panel data analysis method, the first equation uses a random effect model and the second equation uses a fixed effect model.
\end{abstract}

Finding / Originality: That government transfers and gross regional domestic product have a positive and significant effect on regional spending. By using two measures of fiscal stress, it is found that the fiscal stress variable, both through the ratio of original local income to regional spending, and the difference in expenditures and regional revenues, has a significant and positive effect on regional spending

Keywords: Regional spending and fiscal stress

\section{PENDAHULUAN}

Akomodasi dari pemikiran tentang desentralisasi tertuang dalam UndangUndang Nomor 32 Tahun 2004 tentang pemerintah daerah. Konsekuensi yang timbul dari kebijakan otonomi bahwa daerah memiliki kewenangan dan tanggung jawab yang lebih besar untuk pemenuhan kebutuhan masyarakat dan pembangunan daerahnya sejalan dengan tujuan pembangunan nasional. Tanggung jawab ini patut direspon positif yang mengindikasikan bahwa daerah wajib berwawasan cukup luas, pengembangan kualitas dan kuantitas sumberdaya manusia yang berdaya saing serta kemampuan mengelola anggaran secara akuntabel.

\footnotetext{
${ }^{1}$ Fakultas Ekonomi dan Bisnis, Universitas Papua

${ }^{2}$ Fakultas Ekonomi dan Bisnis, Universitas Papua

${ }^{3}$ Fakultas Ekonomi dan Bisnis, Universitas Cenderawasih
} 
Kewenangan lebih luas dalam otonomi daerah diikuti dengan perimbangan keuangan. Dalam UU Nomor 33 Tahun 2004 bahwa perimbangan keuangan antar pusat dan daerah merupakan suatu sistem pembagian yang adil, proporsional, demoktratis, transparan dan efisien. Saragih (2003) mengungkapkan bahwa perimbangan keuangan dalam bentuk desentralisasi fiskal merupakan proses distribusi anggaran dari level pemerintah pusat ke level pemerintah yang lebih rendah guna menjalankan peran di daerah sesuai wewenangnya. Dana transfer pemerintah pusat dialokasikan dalam memenuhi kebutuhan fiskal daerah yang berperan sebagai penyeimbang dan pemerataan fiskal antar daerah. Bastian (2006), menyatakan bahwa transfer pemerintah pusat merupakan suatu sistem pembiayaan yang mencakup pembagian anggaran dan pemerataan antar daerah searah tanggungjawab dan kewenangan dalam pengelolaan keuangan. Respon daerah terhadap dana transfer cenderung beragam dikarenakan potensi sumberdaya dan permasalahan yang berbeda antara satu daerah dengan daerah lainnya sehingga dana transfer diharapkan dapat mengurangi kesenjangan fiskal antar daerah dan mampu memenuhi kebutuhan fiskal yang belum dapat dipenuhi dengan pendapatan asli daerah. Salah satu peran pemerintah menurut Musgrave (1959) yakni peranan distribusi yang dalam menjalankan desentralisasi maka pemerintah mengupayakan agar pendapatan didistribusikan relatif merata. Transfer pemerintah pusat bersumber dari Anggaran Pendapatan dan Belanja Negara (APBN) yang dialokasikan ke daerah untuk memenuhi kebutuhan daerah dalam meningkatan pelayanan kepada masyarakat. Adi (2007) bahwa partisipasi masyarakat cukup penting dalam mewujudkan kemandirian daerah.

Kewenangan fiskal daerah berpedoman pada prinsip agar alokasi sumber daya lebih efisien dan efektif, dengan pertimbangan konektivitas pada masyarakat 
daerahnya sehingga diasumsikan daerah lebih memahami kondisi dan cepat dalam merespon dibandingkan dengan pemerintah pusat. Salah satu kewenangan fiskal yakni belanja daerahyang berperan membiayai pelaksanaan urusan pemerintahan daerah. UU Nomor 32 Tahun 2004 bahwa belanja daerah diprioritaskan untuk melindungi dan meningkatkan kualitas kehidupan masyarakat.

Papua Barat yang terdiri dari tiga belas kabupaten/kota dalam mewujudkan kemandirian daerahnya maka kekuatan berbasis perekonomian daerah harus mampu dioptimalkan. Sebagai daerah yang terus meningkatkan pembangunan yang berkesinambungan maka belanja daerah merupakan instrumen penting dalam hal peningkatan kualitas kehidupan masyarakat. UU Nomor 33 Tahun 2004 bahwa belanja daerah merupakan semua kewajiban daerah yang diakui sebagai pengurang nilai kekayaan bersih dalam periode tahun anggaran yang bersangkutan. Peraturan Menteri Dalam Negeri Nomor 13 Tahun 2006 tentang Pengelolaan Keuangan Daerah menyatakan bahwa belanja daerah meliputi semua pengeluaran dari rekening umum kas daerah. Dalam melaksanakan urusan pemerintahan, belanja daerah digunakan untuk mendanai kewenangan provinsi atau kabupaten/kota.Perkembangan belanja daerah Provinsi Papua Barat berdasarkan kabupaten/kota dapat dilihat pada figure berikut.

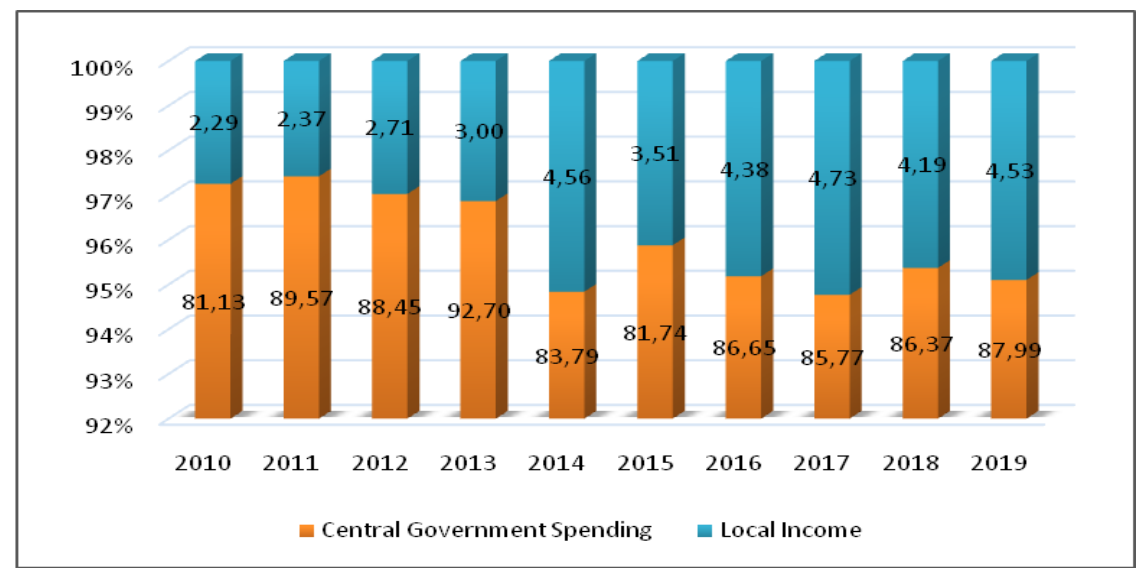

Sumber: BPS dan Kemenkeu RI, 2020

Figure 1. Percentage of Central Government Tranfers and Local Income to Regional Spending in West Papua, 2010-2019 
Figure 1 menunjukkan persentasi kontribusi transfer pemerintah pusat dan pendapatan asli daerah terhadap belanja daerah. Kontribusi transfer pemerintah pusat cenderung berfluktuasi dengan rata-rata sebesar 86.42 persen. Tahun 2013 kontribusi transfer pemerintah pusat mencapai 90.7 persen. Kontribusi transfer pemerintah pusat yang besar mengindikasikan ketergantungan Provinsi Papua Barat masih tinggi. Turnbull (1998) bahwa inefisiensi menyebabkan tingginya belanja daerah. Elmi (2002) mengungkapkan bahwa target utama kebijakan dana transfer pemerintah pusat yakni pemberdayaan masyarakat dan merangsang pembangunan serta kapasitas pemerintah daerah. Kabupaten Bintuni merupakan daerah dengan dana transfer tertinggi di Papua Barat rata-rata pertumbuhan tahunan mencapai 15 persen. Sementara rata-rata pertumbuhan tahunan transfer pemerintah pusat terendah yakni Kabupaten Manokwari rata-rata sebesar 6.13 persen. Lebih lanjut pada pertumbuhan pendapatan asli daerah terdapat kecenderungan peningkatan walaupun kecildengan rata-rata 3.63 persen. Kabupaten Manokwari dengan pertumbuhan pendapatan asli daerah tertinggi mencapai 37 persen dan terendah Kabupaten Kaimana sebesar 12.48 persen. Pertumbuhan pendapatan pajak maupun retribusi daerah menunjukkan perkembangan yang fluktuatif dan sangat curam, peningkatan pajak daerah bahkan mencapai 1000 persen dan penurunannya mencapai 91 persen yang terjadi pada Kabupaten Sorong Selatan, kondisi ini juga terjadi pada wilayah lainnya dengan persentase berbeda. Undang-undang menyatakan bahwa dana transfer pemerintah pusat bersifat hibah terkait pemerataan fiskal, hal ini mendatangkan tanggung jawab yang besar bagi daerah dalam pemanfaatan yang optimal menuju kemandirian daerah. Pengelolaan anggaran antar daerah sewajarnya mempertimbangkan potensi, permasalahan dan solusi maka tak jarang muncul tekanan-tekanan dalam memenuhi harapan pemerintah pusat. 
Otonomi daerah berimplikasi semakin luasnya wewenang pemerintah daerah namun kenyataannya, kepemilikan sumber-sumber penerimaan potensial dari pendapatan asli daerah maupun dari sumber kekayaan alam pada masing-masing daerah tidak merata sehingga hal ini berdampak pada tingkat ketergantungan. Shamsub \& Akoto (2004) mengungkapkan bahwa kriteria daerah dengan pendapatan rendah cenderung memaksimalkan potensi perpajakan, pengeluaran agregat yang tinggi terkait dengan fiscal stress yang tinggi. Stone (2015) adanya desentralisasi seharusnya posisi keuangan pemerintah daerah lebih kuat terkait penyediaan barang publik lokal yang sesuai preferensi masyarakat namun pada kenyataannya keuangan pemerintah daerah justru menjadi lemah. Chung \& Williams (2020) mengungkapkan bahwa daerah yang memiliki tingkat fiskal stress rendah cenderung mampu meningkatkan kondisi keuangannya dalam jangka pendek dibanding daerah yang tingkat fiskal stress tinggi.

Arnett B. S (2012) menggambarkan fiskal stress secara umum sebagai kondisi keuangan yang lemah. Kondisi tekanan fiskal yang terdampak dari keterbatasan anggaran penerimaan daerah yang dapat berpengaruh cukup besar terhadap penyelenggaraan dan penyediaan barang publik. Gorina \& Craig (2016) menyatakan bahwa kondisi ketidakmampuan pemerintah daerah memenuhi kebutuhan fiskal dalam rangka penyediaan pelayanan publik menyebabkan terjadinya fiskal stress. Dalam mengurangi ketergantungan pada pemerintah pusat maka penerimaan daerah harus ditingkatkan kondisi ini cenderung memicu tingkat fiskal stress semakin besar.

Uraian di atas menjadi dasar pijakan dalam mencapai tujuan penelitian yaknimengetahuipengaruh transfer pemerintah pusat dan fiscal stress terhadap belanja daerah kabupaten/kota di Provinsi Papua Barat. Batasan penelitian ini yakni 
mencakup 9 kabupaten/kota dari 13 kabupaten/kota di Provinsi Papua Barat dikarenakan ketersediaandata.

\section{KAJIAN PUSTAKA}

\section{Belanja Daerah}

Peraturan Menteri Dalam Negeri Nomor 13 Tahun 2006 mengklasifikasikan belanja dalam tiga bagian besar, yakni belanja menurut urusan wajib, belanja menurut urusan pilihan, belanja menurut urusan pemerintahan, organisasi, fungsi, program dan kegiatan serta jenis belanja. Belanja daerah digunakandalam rangka pelaksanaan urusan yang menjadi wewenang pemerintah pada tingkat provinsi maupun kabupaten/kota. Inefisiensi, pemborosan dan kebocoran mungkin dapat terjadi dalam pengelolaan belanja daerah sehingga dalam menguranginya pemerintah wajib memperhatikan value for money dalam menjalankan aktivitasnya.

\section{Dana Perimbangan}

UU Nomor 33 Tahun 2004 menyatakan bahwa dana perimbangan adalah dana yang bersumber dari Anggaran Pendapatan dan Belanja Negara (APBN) yang dialokasikan kepada daerah untuk mendanai kebutuhan daerah dalam rangka pelaksanan desentralisasi. Djaenuri (2012) mengatakan bahwa dana perimbangan bersumber dari APBN untuk mendukung kewenangan pemerintah daerah melaksanakan otonomi, terutama peningkatan pelayanan dan kesejahteraan masyarakat yang semakin baik.

Dana perimbangan terbagi atas dana alokasi umum (DAU), dana alokasi khusus (DAK) dan dana bagi hasil $(\mathrm{DBH})$. DBH bersumber dari pendapatan APBN yang pengalokasiannya berdasarkan angka presentase untuk mendanai kebutuhan daerah dalam rangka desentralisasi. DAK bersumber dari APBN yang diberikan 
kepada daerah tertentu dalam rangka pemenuhan kegiatan khusus. DAU bersumber dari APBN yang dialokasikan kepada daerah dengan tujuan pemerataan kemampuan keuangan antar daerah untuk mendanai kebutuhan daerah dalam rangka pelaksanaan desentralisasi.

\section{Fiscal Stress}

Dapat dikatakan bahwa fenomena fiscal stress terjadi pada saat permintaan terhadap pelayanan pemerintah meningkat oleh masyarakat di daerah namun peningkatan ini tidak diikuti dengan peningkatan pendapatan pemerintah daerah. Seperti yang dikemukakan oleh Gorina \& Craig (2016) bahwa fiskal stress merupakan suatu kondisi ketidakmampuan pemerintah daerah memenuhi kebutuhan fiskal dalam rangka penyediaan pelayanan publik.

Shamsub \& Akoto (2004) mengungkapkan terdapat tiga penyebab timbulnya fiskal stress, 1) siklus ekonomi, dimana dalam siklus ekonomi terdapat kondisi resesi, 2) tidak adanya rangsangan dalam perekonomian dan perkembangan negatif industri, berpengaruh terhadap pendapatan pemerintah dari sisi pajak yang stagnan bahkan menurun, 3) faktor politik dan keuangan yang tidak terkontrol.

\section{Produk Domestik Regional Bruto}

Untuk mengetahui kondisi perekonomian suatu daerah dalam kurun waktu tertentu umumnya menggunakan Produk Domestik Regional Bruto (PDRB) (Sukirno, 2000). Badan Pusat Statistik (2020) bahwa PDRB merupakan jumlah nilai keseluruhan semua barang dan jasa yang dihasilkan dalam suatu wilayah dalam jangka waktu tertentu (biasanya satu tahun). Selanjutnya menurut BPS bahwa PDRB dapat digunakan antara lain sebagai indikator untuk mengetahui pertumbuhan ekonomi suatu daerah, sebagai bahan analisis tingkat kemakmuran masyarakat dan 
tingkat perubahan barang dan jasa, sebagai bahan analisis produktivitas sektoral, serta sebagai alat kontrol untuk dalam menentukan kebijakan pembangunan daerah.

\section{METODOLOGI}

Penelitian ini menggunakan jenis data panel yang merupakan gabungan data time series tahun 2010 - 2019 dan cross section kabupaten/kota di Provinsi Papua Barat. Data diperoleh dari Badan Pusat Statistik dan Kementerian Keuangan Republik Indonesia. Metode analisis regresi data panel yang digunakanakan membandingkan hasil regresi tiga pendekatan yaitu pendekatan common effect, fixed effect dan random effect. Menurut Gujarati (2003) terdapat beberapa manfaat penggunaan regresi panel, antara lain: permasalahan heterogenitas individu dapat diatasi, memberikan lebih banyak informasi, lebih banyak variasi, menangkap dinamika perubahan data dan meminimumkan bias serta efisien. Hsiao (2014) juga mengungkapkan data panel dapat memberikan degree of freedom yang lebih besar, variabilitas data lebih besar dan meminimumkan kolinieritas antar variabel independen.Model penelitian diformulasikan dalam bentuk persamaan logaritma natural berikut ini.$$
\ln B D_{i t}=\alpha_{0}+\alpha_{1} \ln D A U_{i t}+\alpha_{2} \ln D A K_{i t}+\alpha_{3} \ln D B H_{i t}+\alpha_{4} \ln D O K_{i t}+\alpha_{5} R P A D_{i t}+
$$$$
\alpha_{6} \ln T x_{i t}+\alpha_{7} \ln P D R B_{i t}+e_{i t} \ldots \text { (1) }
$$$$
\ln B D_{i t}=\alpha_{0}+\alpha_{1} I n D A U_{i t}+\alpha_{2} I n D A K_{i t}+\alpha_{3} I n D B H_{i t}+\alpha_{4} I n D O K_{i t}+\alpha_{5} S P P_{i t}+\alpha_{6} I n T x_{i t}+
$$$$
\alpha_{7} \ln P D R B_{i t}+e_{i t} \ldots
$$

Dimana:BD= belanjadaerah; DAU =dana alokasi umum; DAK = dana alokasi khusus; $\mathrm{DBH}=$ dana bagi hasil;DOK= dana otonomi khusus; $\mathrm{Tx}=$ pajak daerah; $\mathrm{PDRB}$ $=$ produk domestik regional bruto; $\alpha_{0}=$ konstana; $\alpha_{1}, \alpha_{2}, \alpha_{3} \alpha_{4}, \alpha_{5}, \alpha_{6}$, dan $\alpha_{7}=$ koefisien regresi, dan; $e=$ error term. Fiscal stress tidak memiliki definisi baku yang diterima secara umum sehingga definisi dibuat sesuai tujuan penelitian atau dengan 
modifikasi penelitian sebelumnya, Arnett B. S (2012). Terdapat beragam cara untuk mengukur fiskal stress, penelitian ini menyoroti fiskal stress menggunakan dua indikator pada persamaan regresi panel yang terpisah, yang pertama pada persamaan (1) dengan menggunakan rasio pendapatan asli daerah terhadap belanja daerah (RPAD)mengacu pada Brown (1993), dan selanjutnya persamaan (2) menggunakan selisih pengeluaran pemerintah daerah dengan penerimaan daerah (SPP) mengacu pada Skidmore dan Scorsone (2011).Ukuran fiskal stress dalam penelitian ini digunakan dengan pertimbangan ketersediaan data pada instansi terkait yang dapat diakses secara publik.

Variabel dependen dalam penelitian ini adalah belanja daerah merupakan seluruh kewajiban daerah yang diakui sebagai pengurangan nilai kekayaan bersih tiap kabupaten/kota di Provinsi Papua Barat dalam tahun anggaran bersangkutan, satuan rupiah. Variabel independen terdiri dari : dana alokasi umum, merupakan alokasi dana bertujuan pemerataan kemampuan keuangan antar daerah untuk membiayai kebutuhan daerah kabupaten/kota di Provinsi Papua Barat, dalam satuan rupiah;dana alokasi khusus, merupakan alokasi dana bertujuan membantu membiayai kegiatan khusus yang menjadi urusan daerah kabupaten/kota di Provinsi Papua Barat, dalam satuan rupiah;dana bagi hasil, merupakan alokasi dana berdasarkan angka persentase untuk kebutuhan daerah kabupaten/kota di Provinsi Papua Barat, dalam satuan rupiah; dana otonomi khusus, merupakan alokasi dana untuk mendanai pelaksanaan otonomi khusus kabupaten/kota di Provinsi Papua Barat, dalam satuan rupiah;rasio pendapatan asli daerah terhadap belanja daerah, merupakan indikator untuk memeriksa tekanan keuangan daerah dengan melihat kontribusi pendapatan asli daerah terhadap belanja daerah, dalam satuan persen;selisih pengeluaran dan penerimaan daerah, merupakan indikator untuk 
memeriksa tekanan fiskal daerah dengan melihat selisih pengeluaran yang dilakukan oleh pemerintah daerah dengan penerimaan, dalam satuan rupiah; pajak daerah, merupakan kontribusi wajib pajak untuk keperluan daerah untuk kebutuhan masyarakat, dalam satuan rupiah dan; produk domestik regional bruto merupakan indikator untuk mengetahui kondisi perekonomian suatu daerah, dalam satuan rupiah.

Analisis regresi data panel umumnya membandingkan tiga pendekatan, yaitu pendekatan common effect, fixed effect dan random effect. Hasil regresi terbaik dari ketiga pendekatan tersebutyang akan digunakan selanjutnya, maka perlu dilakukan pengujian untuk mendapatkan hasil terbaik. Untuk hasil regresi terbaik antara pendekatan common effect dengan fixed effext digunakan uji Chow, uji Lagrange Multiplier digunakan untuk membandingkan hasil regresi pendekatan common effect dengan random effect dan untuk mendapatkan hasil terbaik antara hasil regresi fixed effect dengan random effect digunakan uji Hausman.Pengujian asumsi klasik dalam penelitian ini untuk mendapatkan hasil estimasi yang lebih baik. Untuk mendeteksi adanya heteroskedastisitas digunakan uji Glesjer, untuk mendeteksi adanya otokorelasi digunakan uji Durbin-Watson dan untuk mendeteksi multikolinieritas digunakan matriks korelasi.

\section{HASIL DAN PEMBAHASAN}

Untuk mendapatkan pendekatan terbaik maka selanjutnya hasil regresi akan di uji. Uji Chow, jika hasil uji menunjukkan nilai probabilitas lebih kecil dari alpha 5 persen maka pendekatan fixed effect lebih baik dibandingkan common effect, sebaliknya common effect lebih baikdigunakan apabila nilai probabilitas lebih besar. Hasil uji Chow memperlihatkan nilai probabilitas persamaan (1) sebesar 0,0259 dan

persamaan (2) sebesar 0,0001 karena nilai probabilitas lebih kecil dari alpha 5 
persen maka pendekatan terbaik untuk kedua persamaan yakni pendekatan fixed effect. Hasil uji Chow mengindikasikan bahwa uji Lagrange Multiplier tidak perlu dilakukan. Selanjutnya, untuk membandingkan pendekatan fixed effect dengan random effect digunakan uji Hausman, jika nilai probabilitas uji lebih besar dari alpha 5 persen maka pendekatan random effect lebih baik dibandingkan fixed effect dan sebaliknya. Nilai probabilitas uji Hausman persamaan (1) sebesar 0,0628 mengindikasikan bahwa pendekatan terbaik yakni random effect, sementara nilai probabilitas persamaan (2) sebesar 0,000 yang mengindikasikan bahwa pendekatan terbaik untuk persamaan kedua adalah fixed effect. Hasil uji regresi panel persamaan (1) dan (2) dapat dilihat pada tabel berikut ini.

Tabel 1.Uji Pendekatan Terbaik

\begin{tabular}{|l|c|c|c|c|}
\hline & \multicolumn{2}{|c|}{ Uji Chow } & \multicolumn{2}{c|}{ Uji Hausman } \\
\cline { 2 - 5 } & $\begin{array}{c}\text { Statistik Chi- } \\
\text { sq }\end{array}$ & Prob. & $\begin{array}{c}\text { Statistik Chi- } \\
\text { sq }\end{array}$ & Prob. \\
\hline Persamaan 1 & 15,77623 & 0,0259 & 13,4055 & 0,0628 \\
\hline Persamaan 2 & 32,7791 & 0,0001 & 32,2015 & 0,0000 \\
\hline
\end{tabular}

Sumber : data diolah, 2021 Eviews

Berdasarkan hasil uji Chow dan uji Hausman maka persamaan (1) menggunakan pendekatan random effect sementara persamaan (2) menggunakan pendekatan fixed effect. Hasil estimasi keua persamaan tersebut dapat dilihat pada tabel berikut ini.

Tabel 2. Hasil Estimasi Regresi Panel

\begin{tabular}{|c|c|c|c|c|}
\hline \multirow[b]{2}{*}{ Variabel } & \multicolumn{2}{|c|}{ Persamaan 1} & \multicolumn{2}{|c|}{ Persamaan 2} \\
\hline & Koef. & t-Stats. & Koef. & t-Stats. \\
\hline InDAU & $0.509285^{\text {*** }}$ & 10.28541 & $0.397568^{* \star *}$ & 9.045215 \\
\hline InDAK & $0.157836^{* \star \star}$ & 8.148056 & $0.089149^{\star * *}$ & 5.950966 \\
\hline InDBH & $0.179693^{\star \star *}$ & 7.402507 & $0.169399^{* \star *}$ & 9.642384 \\
\hline InDOK & $0.167892^{\star \star *}$ & 6.740143 & $0.190648^{\star * *}$ & 12.62643 \\
\hline $\ln T x$ & $0.024703^{\star \star}$ & 2.054929 & 0.006928 & 0.687967 \\
\hline InPDRB & $0.046116^{* *}$ & 2.276323 & $0.302005^{\star \star *}$ & 5.371770 \\
\hline RPAD & $0.007506^{\star \star}$ & 2.155765 & & \\
\hline SPP & & 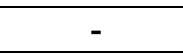 & $7.60 \mathrm{E}-13^{\star * *}$ & 13.64342 \\
\hline$C$ & 0.904689 & 0.801448 & 1.028242 & 0.989469 \\
\hline
\end{tabular}




\begin{tabular}{|c|c|c|c|c|}
\hline \multirow{2}{*}{ Variabel } & \multicolumn{2}{|c|}{ Persamaan 1} & \multicolumn{2}{|c|}{ Persamaan 2} \\
\hline & Koef. & t-Stats. & Koef. & t-Stats. \\
\hline R-square & 0.944982 & & 0.986666 & \\
\hline F-Stats & 201.2012 & & 365.0590 & \\
\hline Prob. & 0.000000 & & 0.000000 & \\
\hline D-W & 1.603415 & & 1.547937 & \\
\hline
\end{tabular}

Sumber: data diolah, 2021 Eviews

Keterangan: ${ }^{* * *}$ sig. 1 persen; ${ }^{* *}$ sig. 5 persen.

Tabel 2 menunjukkan bahwa pada persamaan (1) terdapat empat variabel yang secara signifikan berpengaruh terhadap belanja daerah dengan alpha 1 persen yakni dana alokasi umum, dana alokasi khusus, dana bagi hasil dan dana otonomi khusus. Sementara rasio pendapatan asli daerah, pajak daerah dan produk domestik regional bruto juga berpengaruh signifikan dengan alpha 5 persen terhadap belanja daerah. Pada persamaan (2) terdapat enam variabel yang berpengaruh positif dengan signifikansi alpha 1 persen terhadap belanja daerah, yaitu dana alokasi umum, dana alokasi khusus, dana bagi hasil, dana otonomi khusus, produk domestik regional bruto dan selisih pengeluaran dan penerimaan.Sementara pajak daerah tidak signifikan.

Meski masih perdebatan namun untuk mendapatkan hasil estimasi yang tepat, konsisten dan tidak bias (best linier unbiased estimator) dalam penelitian ini menerapkan uji asumsi klasik. Uji Glesjer untuk mendeteksi heteroskedastisitas, jika hasil uji menunjukkan nilai probabilitas masing-masing variabel independen lebih besar dari alpha 5 persen maka tidak terjadi heteroskedastisitas dan jika nilai probabilitas lebih kecil maka terjadi heteroskedastisitas Ekananda (2016). Hasil uji Glesjer dapat dilihat pada tabel 3 berikut ini.

Tabel 3. Hasil Uji Glesjer

\begin{tabular}{|c|c|c|c|}
\hline Variable & Persamaan 1 & Persamaan 2 & Keterangan \\
\hline C & 0.0752 & 0.1107 & \multirow{2}{*}{ Non } \\
\hline InDAU & 0.1030 & 0.0919 & Heteroskedastisitas \\
\hline InDAK & 0.4101 & 0.3762 & \\
\hline InDBH & 0.7569 & 0.8107 & \\
\hline InDOK & 0.0714 & 0.2028 & \\
\hline
\end{tabular}




\begin{tabular}{|c|c|c|c|}
\hline Variable & Persamaan 1 & Persamaan 2 & \multirow{2}{*}{ Keterangan } \\
\hline InTX & 0.9738 & 0.4610 & \\
\hline InPDRB & 0.1307 & 0.5724 & \\
\cline { 1 - 3 } RPAD & 0.9811 & - & \\
\hline SPP & - & 0.7344 & \\
\hline
\end{tabular}

Sumber: data diolah, 2021 Eviews.

Tabel 3 bahwa berdasarkan hasil uji Glesjer memperlihatkankeseluruhan variabel untuk persamaan (1) dan persamaan (2) tidakterdapat heteroskedastisitas, nilai probabilitas variabel lebih besar dari alpha 5 persen. Matriks kolinieritas untuk mendeteksi hubungan antar variabel independen,hasil menunjukkan tidak terdapat nilai yang lebih besar dari 0,80 sehingga disimpulkan bahwa tidak terdapat multikolinieritas. Uji Durbin Watson untuk mendeteksi terjadinya otokorelasi dalam hasil regresi. Hasil uji Durbin Watson dapat dilihat pada tabel 2 yaitu sebesar 1,6034 dan 1,5479, nilai d dsebesar 1,494 dan dusebesar 1,827 sehingga dapat disimpulkan bahwa tidak terdapat otokorelasi dalam model.

Pengujian signifikansi koefisien regresi menggunakan uji t dan uji F. Uji $t$ digunakan untuk mengamati secara individu pengaruh variabel independen menjelaskan variasi variabel dependen. Pada alpha 5 persen diperoleh nilai t-tabel sebesar 1,6636 selanjutnya dibandingkan dengan nilai t-hitung pada tabel 2. Nilai thitung pada persamaan (1) terlihat keseluruhan variabel berpengaruh signifikan dengan nilai t-hitung lebih besar dari t-tabel. Sementara pada pada alpha 5 persen persamaan (2) hanya variabel pajak daerah yang tidak signifikan sementara variabel yang lain memiliki nilai t-hitung lebih besar dari t-tabel. Uji $F$ digunakan untuk mengamati secara bersama-sama pengaruh variabel independen terhadap variabel dependen. Nilai F-tabel adalah sebesar 2,122 pada persamaan (1) diperoleh nilai Fhitung sebesar 201,20 dan persamaan (2) sebesar 365,05 kedua persamaan memiliki nilai probabilitas yang sama yakni sebesar 0,000 sehingga dapat disimpulkan bahwa pada kedua persamaan semua variabel independen secara 
bersama-sama berpengaruh terhadap belanja daerah secara signifikan. Nilai Rsquare persamaan (1) sebesar 94,4 dan persamaan (2) sebesar 98,6 menunjukkan bahwa model yang digunakan mampu menjelaskan variasi variabel dependen dengan baik.

Estimasi regresi yang diperoleh dalam penelitian ini menunjukkan bahwa transfer pemerintah pusat berpengaruh signifikan pada meningkatnya belanja daerah. Fiskal stress juga berpengaruh positif dan signifikan terhadap belanja daerah, baik dengan ukuran rasio pendapatan asli daerah terhadap belanja daerah maupun selisih penerimaan dan pengeluaran daerah, artinya terjadinya fiskal stress akibat pendapatan yang stagnan sementara pemenuhan kebutuhan dan pelayanan kepada masyarakat meningkat. Saruc \& Sagbas (2008) bahwa variabel transfer pemerintah pusat ke daerah dan produk domestik bruto berpengaruh positif dan signifikan terhadap upaya pajak, lebih lanjut dikatakan bahwa adanya suatu kondisi dimana pemerintah daerah merespon tranfer pemerintah pusat dengan proporsi belanja daerah lebih besar berasal dari transfer. Skidmore \& Scorsone (2011) menemukan bahwa wilayah dengan pendapatan daerah dari pajak yang stagnan atau bahkan menurun mengalami tekanan fiskal yang relatif besar, juga diungkapkan bahwa transfer antar pemerintah juga menjadi sumber fiskal stress yang signifikan, dengan melakukan pemangkasan pengeluaran dan penundaan peningkatan modal merupakan strategi jangka pendek yang efektif namun dalam jangka panjang akan berdampak pada biaya yang lebih besar.

Shamsub \& Akoto (2004) pengeluaran agregat yang tinggi dipengaruhi oleh fiskal stress yang tinggi, bahwa untuk mengurangi fiskal stressmaka pertumbuhan pengeluaran agregat harus dikurangi agar sejalan dengan pertumbuhan pendapatan. Pemerintah negara bagian dan lokal perlu melakukan diversifikasi sumber 
pendapatan guna mengurangi fiskal stress. Juanita \& Abdullah (2016) fiskal stress berpengaruh negatif dan signifikan terhadap perubahan anggaran belanja pemerintah daerah, mengindikasikan bahwa dalam kondisi fiskal stress yang tinggi tingkat fleksibilitas penyesuaian untuk belanja yang dilakukan pemerintah daerah rendah. Muryawan \& Sukarsa (2016) bahwa fiskal stress berpengaruh signifikan terhadap kinerja keuangan daerah dan pertumbuhan ekonomi, dalam upaya meningkatkan penerimaan daerah maka optimalisasi potensi sumber-sumber penerimaan daerah semakin meningkat. Thompson (2017) menganalisis fiskal stress dan menemukan bahwa daerah dengan fiskal stress tinggi cenderung mengurangi total pengeluaran dan meningkatkan pajak.

\section{KESIMPULAN}

Hasil penelitian ini menunjukkan baik pada persamaan (1) maupun persamaan (2), transfer pemerintahpusat dan fiskal stress berpengaruh positif dan signifikan terhadap belanja daerah kabupaten/kota di Provinsi Papua Barat, baik menggunakan rasio pendapatan asli daerah terhadap belanja daerah maupun selisih penerimaan dan pengeluaran pemerintah daerah. Fiskal stress terjadi Ketika pengeluaran yang lebih besar dari penerimaan daerah atau peningkatan belanjadaerah cenderung lebih besar dari peningkatan pendapatan daerah terlebih bila pendapatan daerah mengalami stagnansi atau bahkan menurun. Produk domestik regional bruto juga berpengaruh terhadap belanja daerah.

Dalam rangka pemenuhan kebutuhan dan pelayanan kepada masyarakat kabupaten/kota di Provinsi Papua Barat maka peningkatan penerimaan daerah sebaiknya lebih besar dari pengeluaran daerah, semakin besar proporsi penerimaan daerah terhadap pengeluaran akan semakin baik untuk mencapai kemandirian 
daerah. Penerimaan daerah yang bersumber dari pendapatan asli daerah merupakan kunci kemandirian fiscal daerah, menggali potensi sumber-sumber penerimaan daerah termasuk dengan melakukan diversifikasi seperti pajak dan retribusi diharapkan dapat berdampak pada turunnya fiskal stress dan ketergantungan pada pemerintah pusat.

\section{DAFTAR PUSTAKA}

Adi, P. H. (2007). Kemampuan Keuangan Daerah dan Relevasinya dengan Pertumbuhan Ekonomi. The 1st International Accounting Conference.

Arnett B. S. (2012). Fiscal Stress in The U.S. States: An Analysis of Measures and Responses (Georgia State University). Retrieved from https://scholarworks.gsu.edu/cgi/viewcontent.cgi?article=1035\&context=pmap_di ss

Badan Pusat Statistik. (2020). Produk Domestik Regional Bruto. Retrieved from https://www.bps.go.id/subject/52/produk-domestik-regional-bruto--lapanganusaha-.html

Bastian, I. (2006). Akuntansi Sektor Publik Suatu Pengantar. Jakarta: Erlangga.

Brown, K. W. (1993). The Ten Point Test of Financial Condition: Toward an Easy-toUse Assessment Tool for Smaller Cities. Government Finance Review, 9(6), 21$26 . \quad$ Retrieved from https://localgovernment.extension.wisc.edu/files/2016/04/kenneth-brown-Tenpoint-test.pdf

Chung, I. H., \& Williams, D. (2020). Local Governments' Responses to The Fiscal Stress Label: The Case of New York. Local Government Studies. Taylor and Francis Group. Retrieved from https://doi.org/10.1080/03003930.2020.1797693

Djaenuri, M. A. (2012). Hubungan Keuangan Pusat-Daerah: Elemen-Elemen Penting Hubungan Keuangan Pusat-Daerah. Ghalia Indonesia.

Ekananda, M. (2016). Analisis Ekonometrika Data Panel, Teori Lengkap dan Pembahasan Menyeluruh Bagi Penelitian Ekonomi, Bisnis dan Sosial (Edisi 2). Jakarta: Mitra Wacana Media.

Elmi, B. (2002). Keuangan Pemerintah Daerah Otonomi di Indonesia. Jakarta: UI Press.

Gorina, E., \& Craig, M. (2016). Measuring and Modeling Determinant of Fiscal Stress in US Municipalities. Retrieved from https://www.researchgate.net/publication/326756916_Measuring_and_Modeling _Determinants_of_Fiscal_Stress_in_Us_Municipalities.

Gujarati, D. N. (2003). Basic Econometrics. Singapore: McGraw Hill.

Hsiao, O. (2014). Analysis of Panel Data. New York: Cambidge University Press.

Juanita, A., \& Abdullah, S. (2016). Pengaruh Fiskal Stress dan Legislature Size terhadap Expenditure Change pada Kabupaten/Kota di Sumatera Utara. Jurnal Akuntansi, XX(03), 467-478.

Muryawan, S. M., \& Sukarsa, M. (2016). Pengaruh Desentralisasi Fiskal, Fiskal Stress, dan Kinerja Keuangan Daerah terhadap Pertumbuhan Ekonomi di 
Kabupaten/Kota Provinsi Bali. E-Jurnal Ekonomi Dan Bisnis Universitas Udayana, 5(2), 229-252. Retrieved from https://media.neliti.com/media/publications/44769-ID-pengaruh-desentralisasifiskal-fiscal-stress-dan-kinerja-keuangan-daerah-terhada.pdf

Musgrave, R. (1959). Theory of Public Finance: A Study in Public Economy. New York: McGraw.

Peraturan Menteri Dalam Negeri Nomor 13 Tahun. Tentang Pedoman Pengelolaan Keuangan Daerah. , (2006).

Peraturan Menteri Dalam Negeri Nomor 13 Tahun 2006. Tentang Pedoman Pengelolaan Keuangan Daerah.

Saragih, J. P. (2003). Desentralisasi Fiskal dan Keuangan Daerah dalam Otonomi. Bogor: Ghalia Indonesia.

Saruc, N. T., \& Sagbas, I. (2008). The Surge Impact of the Flypaper, Substitution and Stimulation Effect on Local Tax Effort in Turkey. International Research Journal of Finance and Economics. EuroJournals Publishing Inc, (13), 42-49. Retrieved from https://avesis.istanbul.edu.tr/yayin/200ffeaa-2141-4128-bc664b86f6a6c78e/the-surge-impact-of-the-flypaper-substitution-and-stimulationeffects-on-local-tax-effort-in-turkey

Shamsub, H., \& Akoto, J. B. (2004). State and Local Fiscal Structures and Fiscal Stress. Journal of Public Budgeting, Accounting \& Financial Management.

Skidmore, M., \& Scorsone, E. (2011). Causes and Consequences of Fiscal Stress in Michigan Cities. Regional Science and Urban Economics, 41(4), 360-371.

Stone, S. B. (2015). The Effect of Fiscal Decentralization on the Financial Condition of Municipal Government. International Journal of Public Administration, 38(6), 453-460.

Sukirno, S. (2000). Mikro Ekonomi Modern: Perkembangan Pemikiran dari klasik sampai Keynesian Baru (Edisi 1). PT Raja Grafindo, Jakarta.

Thompson, P. N. (2017). Effects of Fiscal Stress Labels on Municipal Government Finances, Housing Prices, and the Quality of Public Services: Evidence from Ohio. Regional Science and Urban Economics, 64, 98-116.

Turnbull, G. K. (1998). The Overspending and Flypaper Effects of Fiscal Illusion: Theory and Empirical Evidence. Journal of Urban Economics, 44(1), 1-26.

UU Nomor 32 Tahun 2004. Tentang Pemerintah Daerah.

UU Nomor 33 Tahun 2004. Tentang Perimbangan Keuangan Antara Pemerintah Daerah dan Pemerintah Pusat. 